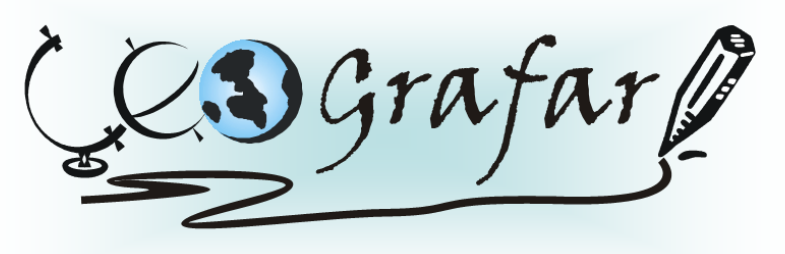

Revista Eletrônica do Programa de Pós-Graduação em Geografia - UFPR

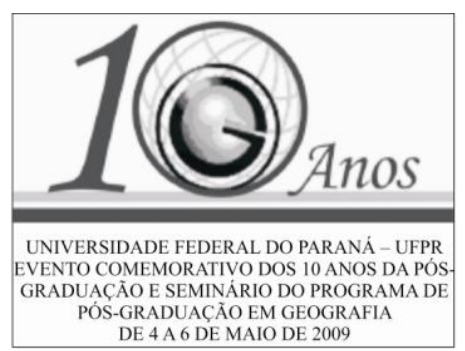

\title{
ESPACIALIZAÇÃO DA REDE HOTELEIRA NO ESTADO DO PARANÁ: PRIMEIRAS CONSIDERAÇÕES.
}

\author{
DANIEL RAMINELLI PÍCCOLO ${ }^{1}$ \\ JOSÉ MANOEL GONÇALVES GÂNDARA ${ }^{2}$ \\ LINHA DE PESQUISA: PRODUÇÃO E TRANSFORMAÇÃO DO ESPAÇO URBANO- \\ REGIONAL.
}

A temática da rede hoteleira e da hotelaria de rede tem sido abordada por turismólogos, administradores e economistas, mas ainda é incipiente da Geografia. Os estudos realizados enfatizam a distribuição espacial e a reestruturação que as mesmas ocasionam na hotelaria instalada, porém tais pesquisas abordam essa questão apenas em capitais brasileiras, como, São Paulo, Curitiba, Porto Alegre e Salvador. Podemos constatar que as redes hoteleiras, seja de capital nacional ou internacional estão presentes, também, em cidades do interior. A presente pesquisa tem por objetivo compreender a distribuição espacial da rede hoteleira, e particularmente a hotelaria de rede no Estado do Paraná, visando tanto a capital quanto as cidades do interior como recorte espacial, analisando principalmente as estratégias de implantação e localização dessas redes e os seus papéis no território. A partir dos objetivos apresentados, levantamos a seguinte questão: Quais são as estratégias para a instalação dessas redes em determinadas cidades do Estado do Paraná? Observamos que em Curitiba e em algumas cidades do interior de maior importância, como, por exemplo, Londrina, Maringá e Cascavel há um crescimento econômico considerável e um advento do turismo de negócios, que acaba atraindo os hotéis de redes. Já em Foz do Iguaçu a motivação principal é a demanda por turismo de lazer. A metodologia da pesquisa consiste em revisão bibliográfica e leituras pertinentes a temática, levantamento de dados e informações, que resultará

\footnotetext{
1.danielpiccolo@ymail.com

${ }^{2}$ Professor orientador
} 
na elaboração de tabelas, gráficos e cartogramas, culminando na redação final do trabalho, que irá comprovar ou refutar a hipótese levantada.

Palavras-chave: Redes hoteleiras; estratégias de localização; Paraná. 